\title{
Helmut Kallmann: Mentor, Colleague, Friend
}

\author{
BY TIMOTHY MALONEY
}

Read at a memorial service for Helmut, February 14, 2012, at Thorncliffe Place Retirement Home, Nepean, Ontario

With the loss of Helmut Kallmann, Canada is a poorer country today. He enriched it for over 70 years, patiently and painstakingly showing us that our musical heritage mattered. His pioneering work led to the creation and preservation of national collections of Canadian sheet music, sound recordings, periodicals, and other publications, as well as archives containing the manuscripts and personal papers of our leading composers and musicians. These documents became source materials not only for his own research, but for that of numerous other scholars who followed his lead in recognizing that the history of music in Canada was a legitimate field of enquiry. The seeds he sowed as a librarian, archivist, curator, historian, lexicographer, and editor, among other activities, have borne fruit for over half a century in the form of histories, biographies, encyclopedias, score anthologies, recordings, documentary films and broadcasts, exhibitions, and university courses devoted to the music of Canada.

In the 1990s, when the National Library of Canada began digitizing some of its "collections of distinction" and making them universally accessible via the Internet, administrators turned multiple times to the music division, which the then National Librarian, Marianne Scott, used to call "the jewel in the crown." Today, much-consulted Web sites such as Sheet Music from Canada's Past, The Virtual Gramophone, the Canadian Music Periodical Index, and The Glenn Gould Archive all celebrate collections that owe their existence to Helmut's vision and initiative.

Beyond his crucial activities in collection-building and scholarship, Helmut played another significant role in fostering the development of music librarianship in Canada through his organizational work with what is now known as the Canadian Association of Music Libraries (CAML), and by establishing ties to its international counterpart, IAML. The profession of music librarianship in Canada flourishes today thanks to Helmut's exemplary leadership, and he has set the bar very high for us, and those who will follow us, to aim for. We salute him as a mentor, colleague, and friend, and we will greatly miss his gentle spirit and humility.

TIMOTHY MALONEY has been the head of the music library and an adjunct professor of music at the University of Minnesota for the past decade. Before that, he was Helmut Kallmann's successor as the director of the National Library of Canada's music division, a post he held for 14 years. A former president of CAML, the Encyclopedia of Music in Canada, and the Canadian Music Centre, he has edited the Canadian Winds/Vents canadiens journal for over a decade and recently contributed over a dozen entries to the forthcoming second edition of the Grove Dictionary of American Music. 